\title{
RESENHA/REVISIÓN/REVIEW
}

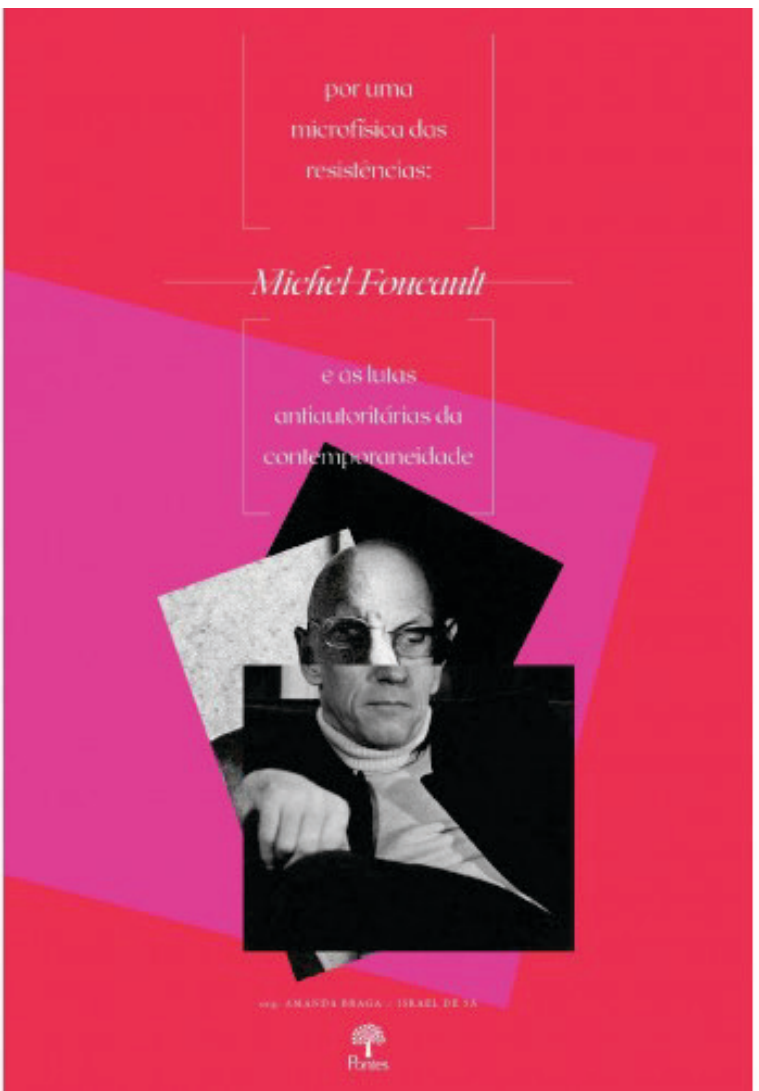

\section{POR UMA MICROFÍSICA DAS RESISTÊNCIAS: MICHEL FOUCAULT E AS LUTAS ANTIAUTORITÁRIAS DA CONTEMPORANEIDADE}

\author{
POR UNA MICROFÍSICA DE LA RESISTÊNCIA: MICHEL FOUCAULT Y LAS LUCHAS ANTIAUTORITARIAS \\ CONTEMPORANEAS
}

FOR A MICROPHYSICS OF RESISTANCE: MICHEL FOUCAULT AND THE CONTEMPORARY ANTI-

AUTHORITARIAN STRUGGLES

Resenhado por

Natália Conceição Silva Barros Cavalcanti ${ }^{*}$

Maria Carolina Xavier da Costa ${ }^{\text {** }}$

Thiago José Ferreira de Sousa ${ }^{* * *}$

Instituto Federal de Educação Ciência e Tecnologia do Pará

\footnotetext{
Doutora em História pela Universidade Federal de Pernambuco. Docente do Instituto Federal de Educaça o Ciência e Tecnologia do Pará-IfPA. Atua na Licenciatura em História do Campus Belém e ensina e orienta nos Programas de Mestrado em Educação Profissional do IFPA e do IFRN. Pesquisadora do Observatório da Diversidade-IFRN-CNPq e GICEP-IFPA-CNPq. E-mail:natalia.cavalcanti@ifpa.edu.br.

Mestranda do Programa de Pós-Graduação em Educação Profissional (PPGEP-IFRN), Especialista em EJA no Contexto da Diversidade. Pesquisadorado Observatórioda Diversidade-IFRN-CNpq. E-mail:c.xavier@ifrn.edu.br.

Docente do Instituto Federal de Educação Ciência e Tecnologia da Paraíba-IFPB. Mestrando do Programa de PósGraduação em Educação Profissional (PPGEP-IFRN). E-mail: thiagojfsousa@hotmail.com.
} 
BRAGA, Amanda.; SÁ, Israel de. Por uma microfísica das resistências: Michel Foucault e as lutas antiautoritárias da contemporaneidade. Campinas, SP: Pontes Editores, 2020.354p.

Organizado pela professora Doutora Amanda Braga do Departamento de Língua Portuguesa e Linguística da UFPB e pelo professor Doutor Israel de Sá da Universidade Federal de Uberlândia, Por uma microfísica das resistências: Michel Foucault e as lutas antiautoritárias da contemporaneidade é uma obra que traduz a atual realidade vivida pelos brasileiros, principalmente os que são alvo da violência e precisam ser resistentes e lutadores. O livro é destinado para aqueles que se debruçam sobre os assuntos da resistência, do poder e das lutas autoritárias sob a perspectiva de Michel Foucault. A obra reúne escritos de quatorze autores, organizados em treze capítulos e dividido em quatro partes. Trata-se, fundamentalmente, de um empreendimento intelectual e político, encampando ele próprio uma forma de resistência.

Na primeira parte, intitulada campo teórico, o pesquisador e professor, Atilio Butturi Junior, professor do Programa de PósGraduação em Linguística da UFSC, contribui com o capítulo Polivalência tática como teoria da resistência em Michel Foucault. Em diálogo com Judith Revel, concentra-se no par resistência/transgressão, no pensamento do filósofo de Poitiers. O autor relaciona a transgressão ao sentido do ágon, ou seja, ao jogo como espécie de condição necessária para pensar o aparecimento das resistências, tomando a leitura de Nietzsche e o uso realizado por Foucault. O capítulo aponta, por meio da análise dos livros de Foucault, publicados entre 1961 e 1976, a invenção de um modelo de resistência que se materializará na nomeada Polivalência tática dos discursos, qual seja, uma rede agonística, exigindo reciprocidade em relação aos poderes, a pluralidade estratégica e a neutralidade ética.

Os organizadores da obra são os responsáveis pelo capítulo Resistir hoje como resistimos ontem: memórias da ditadura civil-militar e o documentário Torre das Donzelas, dando início a segunda parte da obra, com um conjunto de textos que se debruçam sobre resistência e campo político. Trata-se de um capítulo extremamente pertinente e alinhado aos debates políticos do Brasil atual, dando visibilidade ao binômio história e memória numa perspectiva discursiva, dando relevo às problematizações em torno das disputas de narrativas sobre a ditatura civil-militar no Brasil. Por meio da análise de trechos de depoimentos presentes no documentário Torre das Donzelas (2019), dirigido por Suzanna Lira, faz-se um percurso das mutações nas práticas memorialísticas e na escrita da história do período de exceção no Brasil. O documentário brasileiro apreciado apresenta a história de mulheres que foram presas durante a ditadura civil-militar, ao final dos anos 60, em um conjunto de celas femininas no Presídio Tiradentes, em São Paulo, que ficou conhecido como Torre das Donzelas. O cinema emerge como lugar de resistência e materializa discursos que questionam o poder, com a memória agenciando práticas de resistências. O lastro teórico do capítulo, além de Foucault, fundamenta-se em autores como Fréderic Gros, Hannah Arendt e Pierre Nora.

No segundo texto da parte 2, intitulado Discurso político e resistência: a estilística da (des)obediência nos discursos, Vanice Sargentini, professora Visitante na Universidade Federal da Paraíba e Professora Sênior da Universidade Federal de São Carlos, a partir da diferenciação que Pierre Rosanvallon faz entre a política (la politique) e o político (le politique), analisa os modos pelos quais as formas de (des)obediência se enraízam no político. À luz de conceitos problematizados por Michel Foucault e da estilística da obediência de Fréderic Gros, Sargentini realiza uma análise de enunciados representativos do discurso político de gestores do governo, produzidos no ano de 2019 e início de 2020. Os discursos políticos podem orientar formas de comportamento e de obediência. Tendo isso em vista, a discussão ensejada pelo texto de Sargentini demonstra que os discursos políticos analisados se constroem em favor de práticas autoritárias e reacionárias. Esses discursos são sustentados por seguidores subservientes, submissos, conformistas e que compartilham de um consentimento conveniente, evidenciando formas de obediência passiva e irrefletida.

Azemar dos Santos Soares Júnior, professor Adjunto da Universidade Federal do Rio Grande do Norte, inicia o capítulo Histórias de resistência ao coronavírus e ao vírus do autoritarismo, recuperando, em Michel Foucault, o jogo de palavras entre "vida" e "história". Esse jogo é apresentado com o objetivo de introduzir a reconstrução de uma história do tempo presente em que a emergência de um vírus ameaça o fim da vida e, consequentemente, da história do homem. Por mais incrível que possa parecer, em meio a uma pandemia de Covid-19, adotar as medidas sanitárias necessárias para conter a rápida proliferação da doença tem se tornado uma forma de resistência no Brasil, pois o Presidente da República, Jair Bolsonaro, minimiza a gravidade da doença em 
rede nacional. Os embates discursivos gerados a partir dos pronunciamentos governamentais são narrados ao longo do texto a fim de situar-nos acerca dos modos de funcionamento dos discursos. Os enunciados produzidos pelo presidente ora geram a adesão submissa de seus seguidores, ora engendram formas de resistência daqueles que se colocam ao lado da ciência e da vida.

O texto de abertura da parte três é de Cleudemar Alves Fernandes, professor Titular no Instituto de Letras e Linguística da Universidade Federal de Uberlândia. Corpo e Resistência na História do Presente é uma continuação de um estudo anterior, no qual o autor tenta explicitar os lugares e papéis dos sujeitos discursivos em meio a notícias polêmicas de artistas e performances. No texto são citados: Wagner Schwartz: La Bête, Maikon Kempinski: DNA de DAN, Antonio Obá: Atos da Transfiguração: desaparição ou receita para fazer um Santo, Renata Carvalho e a coreógrafa Elisabete Finger, quatro desses artistas se uniram para produzir a peça Domínio Público. A produção teatral é considerada uma produtividade criativa, reflete sobre os ataques sofridos pelos artistas já citados e mostra ser uma ação de resistência às relações de poder. O autor toma a base teórica de Foucault para falar sobre corpo, poder, lutas antiautoritárias e resistência. Sendo o corpo dos artistas um suporte de sujeitos e materialidade discursiva, Fernandes demonstra como pode ser também resistência.

Em Os Atalhos heterotópicos da canção: um devir Caetano como resistência, Pedro Henrique Varoni de Carvalho, pós-doutorando em Informação e Cultura (ECA-USP) e doutor em Linguística (Universidade Federal de São Carlos), realiza uma análise arqueológica da produção musical de Caetano Veloso dos anos 1970, mostrando como, no passado, no contexto da ditadura civilmilitar, existiram diferentes experiências de linguagem e subjetividades que desafiaram o que era possibilitado pela macropolítica. A produção de Caetano foi potência e insurgência no passado, e pode ser sinalizadora de novas possibilidades no contexto adverso contemporâneo. Carvalho aponta como parte da canção popular brasileira produziu-se como resistência política, criando caminhos e linhas de fugas poéticas.

O sétimo texto, intitulado Discurso, poder e resistência em Sangria, de Luiza Romão, é de autoria de Antônio Fernandes Junior, professor Adjunto da Universidade Federal de Goiás. O objetivo do autor é abordar um livro de poesia intitulado Sangria, cuja publicação ocorreu em 2017, sob a influência do golpe de 2016. O autor consegue de forma magnífica desenvolver uma reflexão sobre práticas de resistência construídas no livro, fazendo apontamentos sobre as reflexões arquegenealógicas foucaultianas para mostrar como alguns enunciados dos poemas estão imersos em relações de poder-saber, que são historicamente produzidos e demonstram ser estratégia de resistência aos dispositivos de poder que incidem sobre o corpo feminino. O debate é concentrado no eixo discurso-poder-resistência, dentro do quadro da arqueogenealogia dos discursos.

Feminismos e resistências: viver diferentemente o presente, de Margareth Rago, professora Titular do Departamento de História da UNICAMP, fala sobre assuntos que circundam a temática dos estudos feministas. A autora acentua que, com a contribuição das feministas, discursos foram se descontruindo. A solteirona se tornou a "mulher independente", a maternidade foi deixando de ser a essência feminina. Houve um movimento de autonomização psíquica e emocional que realizou um trabalhou de dessubjetivação nas mulheres. Temas íntimos e privados se tornaram públicos e isso é notado na política, na cultura feminina, na economia, na ciência. Os estudos feministas contribuíram para a desconstrução de narrativas tradicionais que excluíam as mulheres. Denunciaram a dimensão misógina e perversa e criticaram interpretações que reduziam as mulheres como sendo biologicamente inferiores e destinadas a vida privada. Nos anos 1970/80, uma grande biografia feminista foi gerada. No texto também são debatidas questões envolvendo a moral cristã, trazendo à tona debates religiosos que estigmatizam as mulheres. Por último, a autora comenta sobre os neoliberais e como eles investem no controle dos corpos e subjetivação feminina

O texto seguinte é de Bruno Franceschini, professor Adjunto da Universidade Federal de Goiás no curso de Letras e no Programa de Pós-graduação em Estudos da Linguagem. Movimento LGBTQ+ e resistência na contemporaneidade: Pink Money, transgressão e práticas de liberdade debate sobre práticas de resistência do movimento LGBTQ+, trazendo a torna questões referentes aos corpos de seus integrantes em meio ao discurso de Pink Money e Pink Washing e intensificando questões sobre como esses corpos resistem frente à heterocisnormatividade e aos discursos que tentam normalizar suas condutas. $\mathrm{O}$ autor se pauta na arqueologia foucaultiana para trabalhar enunciados. Ele os divide em três séries, expondo reportagens e as analisando em seguida. A primeira série versa sobre enunciados presentes nos discursos dos associados ao Pink Money e Pink Washing; na segunda, ele trata da "vigilância e controle: práticas de normalização das condutas dos corpos LGBTQ+", discutindo a biopolítica, o biopoder, as práticas de objetivação e 
subjetivação de cantoras drags e trans; na última série, aborda as práticas de liberdade e o cuidado de si dos corpos dos artistas LGBTQ+.

No capítulo Da infâmia à resistência: quando se é notícia porque se lê, a professora da UFSCar, Luzmara Curcino, pós-doutora em Linguística e Língua Portuguesa, apresenta uma discussão sensível sobre catadores de lixo e/ou moradores em situação de rua que se tornam notícia porque foram flagrados com livros, debruçando-se, assim como Foucault, em documentos sobre os "infames" contemporâneos. A pesquisadora analisa textos da mídia que tiram, provisoriamente, do anonimato esses sobreviventes do lixo e da miséria, em função do caráter surpreendente de seu interesse por livros e pela leitura. Em diálogo com as obras de Michel Foucault, particularmente o livro A vida dos homens infames, além de Pierre Bourdieu e Passeron, a autora traça uma crítica à espetacularização dessas vidas pela mídia e pela lógica meritocrática dos enunciados que lhes dão visibilidade. Texto denso, crítico e muito pertinente.

O décimo primeiro texto, Necropolítica e violência no Brasil, de autoria de Mozart Linhares da Silva, Professor-Pesquisador no Programa de Pós-graduação em Educação (PPGEDU), analisa a temática da violência racial no Brasil sob a perspectiva da biopolítica, se apropriando dos estudos de Michel Foucault, Agamben, e da necropolítica de Achille Mbembe. Sua tese centra-se na ideia de que, historicamente, a violência no Brasil pode ser tratada como desdobramento de uma necropolítica, de uma política de soberania, pela qual se escolhe quem deve morrer e quem pode viver - sendo pretos, pardos, jovens, pobres, moradores de periferia ou comunidade os maiores alvos da violência em nosso país. Sendo assim, ao longo do texto o autor fundamenta que a violência brasileira tem um viés racial.

No capítulo 5 da terceira parte da obra, intitulado Da oralidade africana como discurso e modalidade parresiástica: implicações para a política linguística, Cristine Gorski Severo, Professora Associada da Universidade Federal de Santa Catarina, reflete, sob a inspiração de Michel Foucault, acerca da oralidade africana como lugar de experiência e namaneira pela qual ela insereve os sujeitos são inscritos em modos específicos de subjetivação. Para a cultura Bambara, por exemplo, o doma ou soma é tido como o conhecedor de um tipo de saber que pode promover tanto a cura como a formação intelectual e moral dos sujeitos. Considerando a oralidade tomada como discurso, Severo recupera reflexões de Burquinense Joseph Ki-Zerbo e de Malinês Amadou Hampâté Bâ. Para ambos, na oralidade africana há uma forte ligação entre o sujeito e a palavra proferida, mas ela não tem apenas valor individual, sendo também valorada pela comunidade que a credita como verdadeira. À guisa de conclusão, a partir das reflexões sobre a "africanidade" tomada como discurso, Severo reflete sobre a possibilidade de uma política linguística por meio da qual a ideia de oralidade transcenda o uso verbal da língua como passível de decodificação fonético-fonológica. Sendo assim, a dimensão discursiva seria elemento regulador do modo de funcionamento das línguas em uma determinada sociedade, incluindo aspectos éticos e políticos da busca pela palavra.

No texto que fecha a coletânea, intitulado Indígenas brasileiros e a microfísica da resistência/resiliência territorial, cultural e linguística, Maria Sílvia Cintra Martins, Professora Sênior da Universidade Federal de São Carlos, reflete sobre o direito legítimo à posse de terras dos povos indígenas, a complexidade da questão do letramento acadêmico perante a chegada dos indígenas às universidades e sobre os processos de resistência/resiliência de povos indígenas habitantes da região Amazônica Alto Rio Negro, localidade de maior densidade demográfica de indígenas brasileiros. O caráter híbrido da língua Nheengatu, de acordo com Martins, é o que mais representa a resistência/resiliência. Os povos indígenas da região decidiram não mais insistir na resistência étnica em relação aos missionários, chegados a partir de 1914, mas sim, empreender formas de aproximação de modo a evitar perdas e conflitos. Dessa forma, o caráter compreensivo do Nheengatu, que adquiriu certas características semelhantes à língua portuguesa, coloca-se como signo estratégico de resiliência desses povos.

A partir do que foi exposto, é possível perceber o cuidado e a preocupação dos organizadores com a publicação. Desde a escolha da belíssima capa, até a esplendida apresentação e organização dos capítulos - en que é possível notar a ligação entre eles, sendo encadeados de forma lógica, precisa e coerente. Notáveis e competentes pesquisadores estão presentes, tornando a obra já com cara de um livro clássico. Já é uma leitura obrigatória para os pesquisadores interessados em Michel Foucault e nos seus debates sobre poder e resistência. Ele nos incentiva a sonhar com dias melhores e a nos manter resistentes, mesmo vivendo no cenário político atual. Resistência e esperança são as palavras que ficam em nossa mente e coração após a pertinente leitura. 


\section{(c) (1) $@ \Theta$}

Recebido em 10/01/2021. Aceito em 15/02/2021 